\title{
Histone H2A Type 1-A
}

National Cancer Institute

\section{Source}

National Cancer Institute. Histone H2A Type 1-A. NCI Thesaurus. Code C162886.

Histone H2A type 1-A (131 aa, 14 kDa) is encoded by the human H2AC1 gene. This protein is involved in chromatin remodeling. 